\title{
Localized pigmented villonodular synovitis in a child knee
}

\author{
Bir çocuk dizinde lokalize pigmente villonodüler sinovit
}

\author{
O. Şahap Atik, MD., ${ }^{1}$ Hasan Hüseyin Bozkurt, MD., ${ }^{1}$ Efkan Özcan, MD., ${ }^{1}$ Batuhan Bahadır, MD., ${ }^{1}$ \\ Murat Uçar, MD., ${ }^{2}$ Betül Öğüt, MD., ${ }^{3}$ Leyla Memiş, MD. ${ }^{3}$ \\ ${ }^{1}$ Department of Orthopedics and Traumatology, Medical Faculty of Gazi University, Ankara, Turkey \\ ${ }^{2}$ Department of Radiology, Medical Faculty of Gazi University, Ankara, Turkey \\ ${ }^{3}$ Department of Pathology, Medical Faculty of Gazi University, Ankara, Turkey
}

\begin{abstract}
Pigmented villonodular synovitis is a benign proliferative tumor of the synovium. It is very rare, and most cases occur in the knee joint. In this article, we report a case of localized pigmented villonodular synovitis in the knee joint of a 14-yearold boy. This condition is rare in the knees of the children. We preferred to remove the tumor with arthrotomy instead of arthroscopy for two reasons: (i) the patient was obese, (ii) we thought that recurrence risk was high after arthrotomy.

Keywords: Child; knee joint; localized pigmented villonodular synovitis.
\end{abstract}

Pigmented villonodular synovitis (PVS) is a benign proliferative disorder of the synovium. It is either in diffuse or localized form. The definitive etiology is unclear. Localized pigmented villonodular synovitis (LPVS) is rare condition in the knee joint. ${ }^{[1]}$ The incidence is 1.8 persons among one million population, and $67 \%$ of cases occur in the knee joint. ${ }^{[2]}$ In this article, we report a case of LPVS in the knee joint of a child which is one of the rare conditions in the knee. $^{[3-5]}$

\section{CASE REPORT}

A 14-year-old boy presented with recently recognized intermittent left knee swelling. Physical examination revealed that swelling was a solid mass with a diameter of $3 \mathrm{~cm}$ (Figure 1). It was apparent in knee extension, and was disappearing during knee flexion. The swelling was painless. The range of motion was
$\ddot{O} Z$

Pigmente villonodüler sinovit sinovyumun iyi huylu proliferatif tümörüdür. Çok nadirdir ve olguların çoğu diz ekleminde oluşur. Bu yazıda, 14 yaşında bir erkek çocuğun diz ekleminde lokalize pigmente villonodüler sinovit olgusu sunuldu. Bu durum çocukların dizlerinde nadirdir. Tümörü artroskopi yerine artrotomi ile çıkarmayı iki nedenle tercih ettik: (i) hasta obez idi, (ii) artrotomi sonrası rekürens riskinin yüksek olduğu düşünüldü.

Anahtar sözcükler: Çocuk; diz eklemi; lokalize pigmente villonodüler sinovit.

within normal limits. A written informed consent was obtained from the patient.

There was no abnormality in knee radiograms. Magnetic resonance imaging showed a soft-tissue tumor in the infrapatellar fat pad (Figure 2).

Arthrotomy of the left knee was performed with a tourniquet under general anesthesia. The findings were normal during arthrotomy. The articular cartilage of patella and femoral condyle was normal; there was no damage. Reddish-brown tumor $(30 \times 30 \times 15 \mathrm{~mm}$ in size) was located in the infrapatellar fat pad (Figure 3, 4).

The patient was allowed to walk with full weight bearing on postoperative first day. He was completely asymptomatic with full range of motion of the knee, no effusion or tenderness and no palpable mass one week after.

- Received: January 09, 2017 Accepted: February 09, 2017

- Correspondence: O. Șahap Atik, MD. Gazi Üniversitesi Tıp Fakültesi Ortopedi ve Travmatoloji Anabilim Dalı, 06500 Beşevler, Ankara, Turkey. Tel: +90 312 - 2025528 e-mail: satikmd@gmail.com 

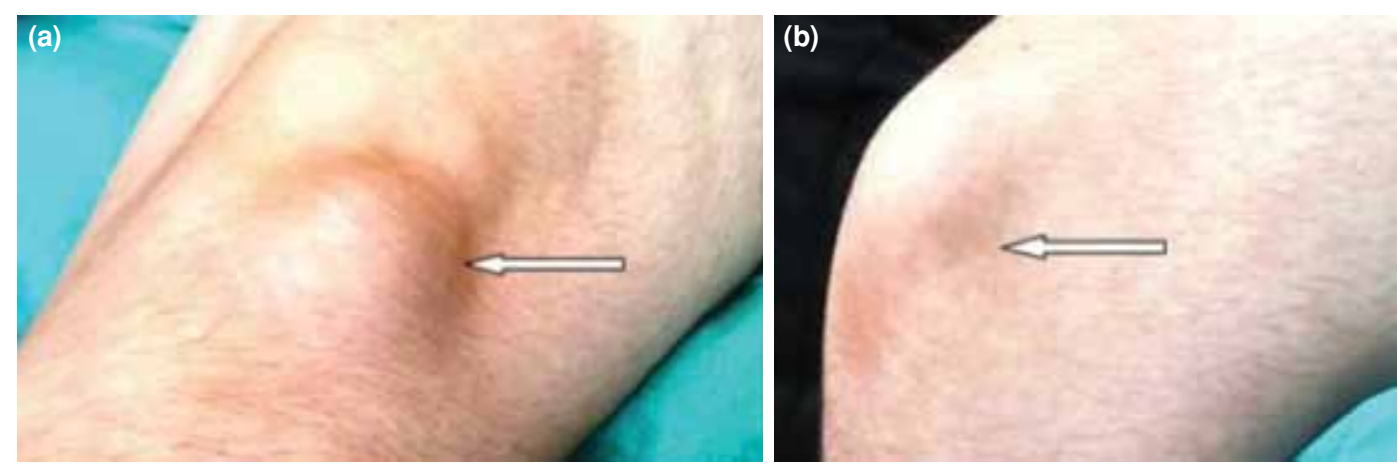

Figure 1. (a) Swelling of left knee in lateral side during extension (arrow). (b) No swelling in flexion.
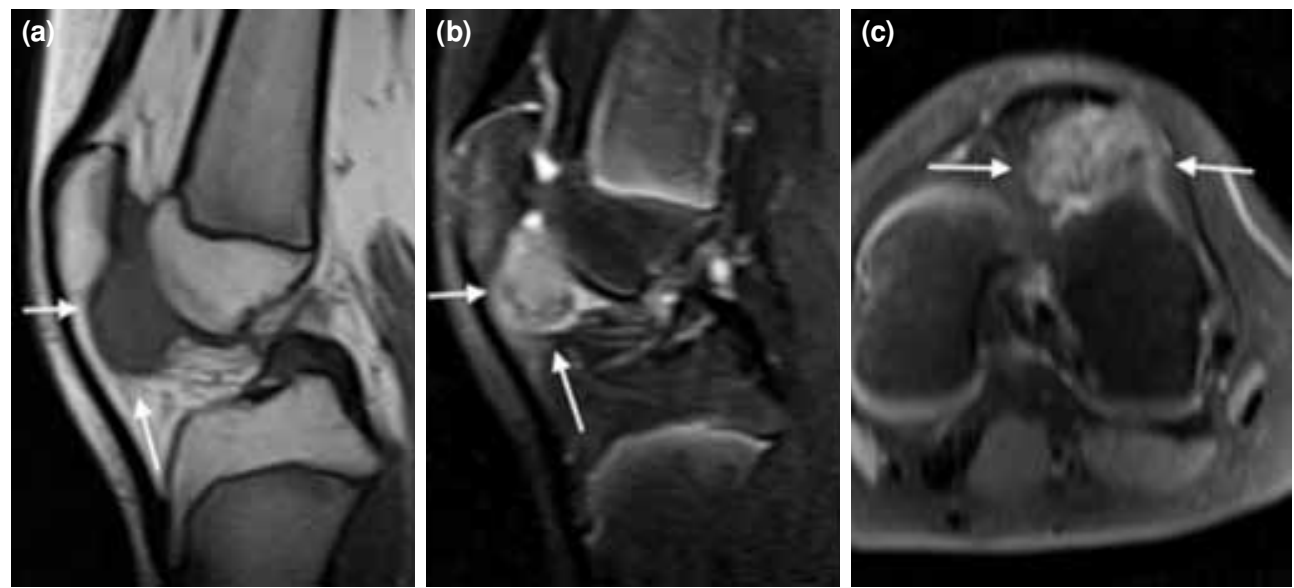

Figure 2. (a) $T_{1}$ weighted, (b) $T_{2}$ weighted with fat saturated sagittal plane, and (c) proton density with fat saturated axial plane images demonstrate soft tissue mass (arrows) in superolateral part of Hoffa's fat pad. Well-defined lesion contains low punctate signal intensity indicating hemosiderin accumulation.

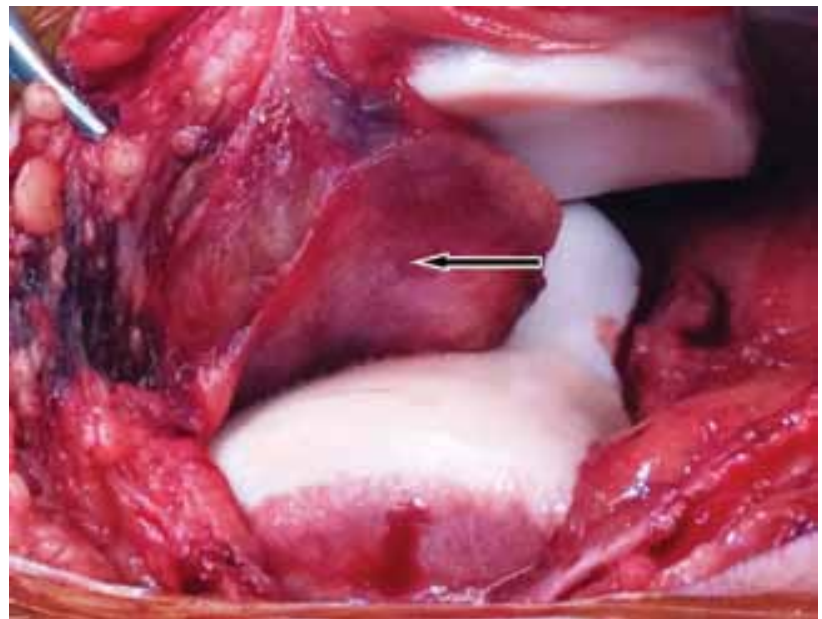

Figure 3. View of localized pigmented villonodular synovitis in infrapatellar fat pad during surgery. Articular cartilage of patella and femoral condyle was normal; there was no damage.

\section{DISCUSSION}

There are case reports of LPVS with various symptoms of the knee. ${ }^{[6-8]}$ The only complaint of our patient was intermittent swelling on the lateral side of the left knee. He was pain free. However, PVS may invade the subchondral bone, producing cysts and erosions. For this reason, we recommend to remove the tumor as early as possible to avoid secondary degenerative lesions.

Magnetic resonance imaging is a valuable diagnostic tool with high sensitivity and specificity, especially when radiograms are negative. ${ }^{[9,10]}$ It may show the hemosiderin deposits within the joint.

We preferred removal of tumor with arthrotomy instead of arthroscopy for two reasons: (i) the patient was obese, (ii) a recurrence rate of $18 \%$ was reported 

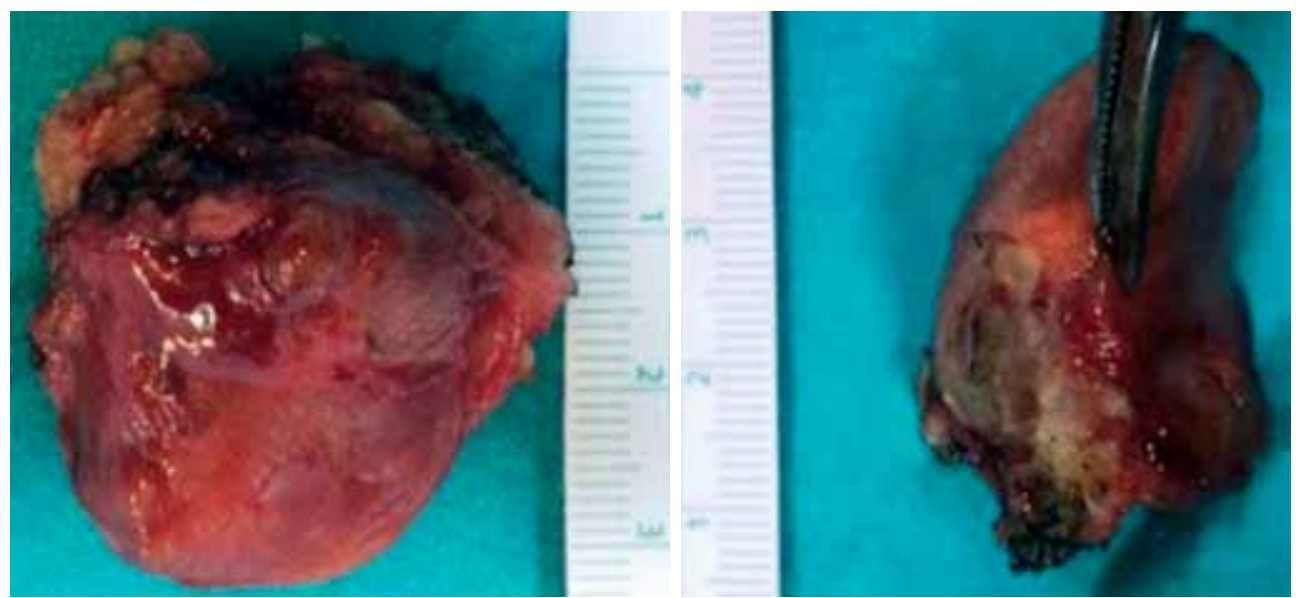

Figure 4. Reddish-brown tumor with size of $30 \times 30 \times 15 \mathrm{~mm}$.
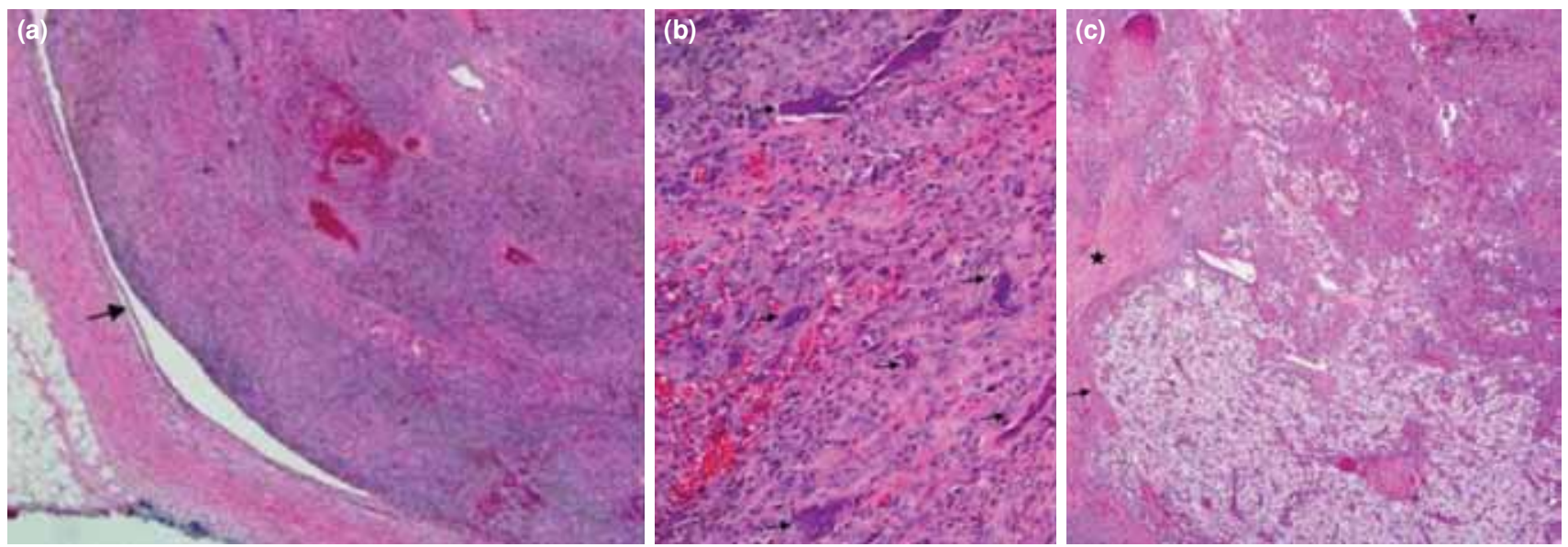

Figure 5. Histopathological examination reveals typical histological features of pigmented villonodular synovitis. (a) Well-circumscribed lobulated mass (arrow) (H-E x 40). (b) Rich areas of giant cells (arrows) (H-E x 200). (c) Foam cells (arrow), collagenous matrix (star), and pigmented areas (arrow head) ( $\mathrm{H}-\mathrm{E} \times 40)$.

in a study in two of 11 cases within 6-9 months after arthroscopic surgery. ${ }^{[11]}$

In conclusion, we think that if the lesion is removed accurately, the recurrence rate may be low in LPVS.

\section{Declaration of conflicting interests}

The authors declared no conflicts of interest with respect to the authorship and/or publication of this article.

\section{Funding}

The authors received no financial support for the research and/or authorship of this article.

\section{REFERENCES}

1. Granowitz SP, Mankin HJ. Localized pigmented villonodular synovitis of the knee. Report of five cases. J Bone Joint Surg Am 1967;49:122-8.

2. Myers BW, Masi AT. Pigmented villonodular synovitis and tenosynovitis: a clinical epidemiologic study of 166 cases and literature review. Medicine (Baltimore) 1980;59:223-38.

3. Atik OŞ. Are all case reports worth publishing? Eklem Hastalik Cerrahisi 2016;27:61.

4. Görmeli G, Görmeli CA, Maraş Özdemir Z, Sevimli R, Akpolat N. A patellar giant-cell tumor with soft tissue involvement: an alternative treatment method and review of the literature. [Article in Turkish] Eklem Hastalik Cerrahisi 2015;26:110-5.

5. Çetinkaya M, Özer H, Selek HY, Erekul S. Total patellectomy for patellar aneurysmal bone cyst. Eklem Hastalik Cerrahisi 2016;27:175-8.

6. Woods C Jr, Alade CO, Anderson V, Ashby ME. Pigmented villonodular synovitis of the knee presenting as a loose body. A case report. Clin Orthop Relat Res 1977;129:230-1.

7. Horiuchi $\mathrm{H}$, Nawata M, Kamijo T, Saito N, Wakitani S, Kobayashi S, et al. Locking of the knee caused by localized pigmented villonodular synovitis: a case report. Mod Rheumatol 2004;14:184-6.

8. Flandry FC, Jacobson KE, Andrews JR. Localized pigmented 
villonodular synovitis of the knee mimicking meniscal injury. Arthroscopy 1986;2:217-21.

9. Mandelbaum BR, Grant TT, Hartzman S, Reicher MA, Flannigan B, Bassett LW, et al. The use of MRI to assist in diagnosis of pigmented villonodular synovitis of the knee joint. Clin Orthop Relat Res 1988;231:135-9.

10. Muscolo DL, Makino A, Costa-Paz M, Ayerza MA.
Localized pigmented villonodular synovitis of the posterior compartment of the knee: diagnosis with magnetic resonance imaging. Arthroscopy 1995;11:482-5.

11. Rhee PC, Sassoon AA, Sayeed SA, Stuart MS, Dahm DL. Arthroscopic treatment of localized pigmented villonodular synovitis: long-term functional results. Am J Orthop (Belle Mead NJ) 2010;39:90-4. 